\title{
Rethinking Masculinity in Disaster Situations: Men's Reflections of the 2004 Tsunami in Southern Sri Lanka
}

\author{
By Lena Dominelli, University of Stirling
}

Email: lena.dominelli@stir.ac.uk

\begin{abstract}
:
The role of men in disasters is rarely discussed in depth and research on this topic is scarce. Yet, masculinity is an important dimension of disasters, whether considering men's active roles in disasters, their position within family relations pre- and post-disasters, or during reconstruction. The research project, Internationalising Institutional and Professional Practices conducted in 12 southern Sri Lankan villages sought to understand men's experiences of supporting their families after the 2004 Indian Ocean Tsunami. It highlighted the importance of patriarchal relations and men's roles as providers throughout the disaster cycle. However, the picture is complicated. While most humanitarian aid is aimed at the generic person, a man, men do not have their needs as men specifically addressed during the receipt of humanitarian aid. Men who receive nothing post-disaster can become desperate, and misuse substances such as alcohol and drugs. This creates situations where men fight each other and abuse women and children within intimate relationships because the tsunami has destroyed their livelihoods and nothing has replaced these. In this article, I examine the complexities men navigate to understand their position when seeking to re-establish their connections to family and community life. I conclude that their specific needs as men require targeted interventions throughout all stages of the disaster cycle, and especially during the delivery of humanitarian aid if they are to fulfil their provider and protector roles and be steered away from behaviour that is abusive of close members of their families: wives, children, and other men.
\end{abstract}

\section{Keywords:}

Men, masculinity(ies), breadwinner/provider, protector, humanitarian aid, disasters, differentiated disaster experiences, family relations, domestic violence, abusive relations

\section{Introduction}

The 2004 Indian Ocean Tsunami, trigged by an 9.3 Mw underwater earthquake off coastal Sumatra on Boxing Day, 26 December 2004 (Poya Holiday in Sri Lanka) affected 12 countries, causing 250,000-300,000 deaths and \$10-15 billion in damages. My research focused on southern Sri Lanka where the Internationalising Institutional and Professional Practices (IIPP) Team collaborated closely with local universities and NGOs to provide relief and support from early January 2005. Sri Lanka had 30,000-40,000 fatalities and extensive damage to transportation, communication and utilities systems, mainly in its southern and eastern territories (Tomita et al., 2006; Poisson et al., 2009). The IIPP Team undertook mainly ethnographic research five years later to ascertain the longer-term impact of the tsunami on people's lives. The IIPP Team consisted of Durham University and three UKbased researchers working closely in southern Sri Lanka with 3 local universities, a highly respected local NGO and 3 local researchers to avoid neo-colonial practices through university involvement (Teichler, 2009) and engage with local people on their terms. The Team has written extensively on the findings. For this article, I focus on masculinity(ies) and men's responses to the post-tsunami situation to contribute to the limited literature on this topic. 
Alhough the relevance of masculinity in disasters and roles that men assume are rarely researched, Australian scholars highlighted this issue during the bushfires of 2009 (Pease, 2014). This paucity leaves a research gap that I contribute towards by examining hegemonic patriarchal masculinity to understand the impact of masculinity(ies) as a socially constructed phenomenon on men, women and children, before, during and after the 2004 Indian Ocean Tsunami in southern Sri Lanka. I examine gender relations through research of 12 villages in the severely affected Galle area. I do this by considering how local people talked about gender relations to theorise and conceptualise masculinity(ies) during, pre- and post-disasters including reconstruction activities. I undertake a literature review to explore existing research on masculinity(ies) in disasters, including gaps in scholarly knowledge that need to be filled through further research. Although the main people who spoke about events in these villages were men, there was no articulation of men's specific needs as men. They referred explicitly to whether or not they could enact their economic provider and protector roles post-tsunami. When men spoke about not receiving funds to resume their fishing past, they did not comment on this as an area of specific need regarding masculinity. This was implied by how they spoke of their social roles as men. Masculinity(ies) was/were assumed. Instead, they focused internally to complain about lacking resources to re-establish fishing activities because otherwise they were incapable of providing for their families. Failing often catapulted them into despair, misusing substances (drugs and alcohol) and perpetrating violence against women, children and other men, and an inability to extricate themselves from such behaviours.

The literature review indicates that masculinity should be conceptualised as masculinities even when one form dominates as hegemonic (Connell and Messerschmidt, 2005: Pacholok, 2005, 2013). Men's roles in disasters are typically linked to being family breadwinners/providers and protectors of women and children who are deemed more vulnerable (Tyler and Fairbrother, 2013). Men's capabilities in meeting their responsibilities as providers and protectors were crucial in how men perceive themselves in the world, before, during and after a disaster. This state of being is fragile and dominance must be reproduced constantly (Kaufman, 2001; Monaghan, 2002; Pacholok, 2009). Through the IIPP research, men's talk exposed the gap between their own, their families' and society's expectations of their socially-prescribed roles and what they could actually achieve posttsunami when men experienced seemingly intractable emotional, financial and social turmoil. This could result in their lashing out in violent responses against women, children and other men, and/or misusing substances, especially drugs and alcohol. Their reality in practice is complex. Aid assumes an ungendered typical human, in which men receive aid on behalf of their families to provide for them. However, inattention to men's specific needs as victim-survivors deprives them of resources necessary to restore their livelihoods and meet expectations about being providers and protectors IIPP's research shows that post-disasters, NGO-funded livelihood projects target women as more trustworthy than men in prioritising family needs and getting children to school with appropriate clothing and books. Additionally, cultural traditions enable men to profit from women's earned income (Parvin et al., 2005) and because men spend funds on their own needs (World Bank, 2005). Exploring what men said about their position, and how villagers described gender relations for both men and women, shows that they did not support a realignment of the 'gender binary' as articulated by Pacholok $(2009,2013)$ and Rushton et al., (2019). However, men who did not own boats, but worked for others, expressed feelings of marginality. The IIPP data implicates both men and women in repeatedly (re)constructing masculinity and femininity (Pacholok, 2009).

The data highlight the: interaction between patriarchal masculinity and femininity; new burdens imposed on women because men had lost their livelihoods; undermining of women's and children's well-being through growing violence from men known to them as family and community members when men failed to resume their livelihoods and roles as family providers and protectors. This situation was exacerbated through violence generated by unknown men engaged in sexual 
predations, human trafficking and armed conflict. IIPP analyses of domestic realities show the limitations cultural restrictions imposed on rural women's capacities to assume new roles and livelihoods and acquire control over decision-making and finances (Montanari and Bergh, 2019), thereby stressing the imperative for further research to explore the impact of masculinity(ies) in disasters and men's roles throughout the disaster cycle (Dominelli, 2012a, b; 2013; 2014), regardless of the point at which disasters enmesh them. I conclude that humanitarian aid workers should address men's specific needs to reduce the risks their abusive behaviours pose to women, children, themselves and other men.

\section{Methodology}

The British Economic and Social Research Council (ESRC) funded the Internationalising Institutional and Professional Practices (IIPP) Project (Grant number ES/F031505/1) during 2009-2012 to explore retrospectively what happened in 12 southern Sri Lankan villages seriously affected by the 2004 Indian Ocean Tsunami. Durham University Ethics Committee granted ethical approval. The IIPP Project employed local researchers who spoke the local languages and English to conduct the interviews. The sample was recruited through snowballing techniques by approaching respondents initially suggested by the local NGO and others they suggested. Everyone approached contacted others and soon most villagers knew about this research. Their engagement resulted in a dataset consisting of 368 interview transcripts, 10 focus groups and 35 sets of field notes from 12 village sites. In these villages, men, including Buddhist monks, held key positions of authority, and facilitated access to research participants. Potential participants received information leaflets explaining the Project's purpose and methodology, and encouraged to ask questions. They were assured that participation was entirely voluntary and that they could withdraw at any time without giving explanation or incurring a penalty. Prior to interview, each participant was asked to complete written informed consent forms. Those giving verbal consent had it recorded. Interviews and focus groups were digitally recorded. If technical problems prevented digital recording, local researchers took notes as close as possible to the exact words spoken and later checked their accuracy with interviewees. Consent forms and interviews were stored in separate password protected files. The data collected was transcribed by local researchers who sent it electronically to the Durham-based researchers for anonymised and confidential storage. Anonymised transcripts were stored with ESRC Archive Data on the Project's completion.

Semi-structured interviews explored their experiences and reflections of the tsunami. The passage of time helped reduce upset when discussing the many tsunami horrors interviewees had witnessed. This provided a wealth of rich data and enabled the application of an interpretive ethnographic methodology to explore their socially constructed realities and contested nature of international interventions (Daly, 2007). It also facilitated access to the 'inside' social worlds of interviewees and the richness, complexities and particularities of villagers' experiences (Berger and Luckmann, 1967). This method holds that knowledge is authentic if it reflects the participants' many voices, makes explicit researchers' epistemological assumptions and values, and informs readers of the specific contexts in which the research occurs (Klein and Myers, 1999). Authenticity was achieved by triangulating the patterns emerging from the interviews, field notes and focus groups and searching for (in)consistency between them (Denizen, 2006). The socially constructed gendered relations in these villages were analysed by focusing on keywords relating to the theme of gender and roles undertaken by men and women prior to, during and after the tsunami. This permitted the interrogation and analysis of what, if any, changes had occurred in their gender relations.

The original data were coded through NVivo software using a grounded analysis method. An open coding scheme was initially utilised, following a grounded process to avoid foisting predefined ideas on the data. The patterns, themes, and categories of analysis emerge when the data collected are 
analysed (Mathbor, 2008: 37). Thus, themes arise from interviewees' priorities and concepts not those of the researchers. In stage 1, rough summaries of the ensuing 105 themes with illustrative quotations were formulated. These summaries were used to break down each stage 1 theme into specific sub-themes that seemed most prominent within that theme. This process was repeated throughout the 105 initial themes and yielded 388 themes which were then regrouped into 12 key areas of results (stage $1 \mathrm{~b}$ ) in a process of 'coding down' from the general themes (stage 1 ) to specific sub-themes (stage $1 \mathrm{~b}$ ). The similar or identical sub-themes that emerged from within more than one stage1 theme facilitated internal verification. Where duplication occurred, themes were merged to produce 301 themes. The stage $1 \mathrm{~b}$ framework was reviewed again to identify themes that lacked specificity and/or clarity and broken down into further sub-themes. This resulted in 357 themes which were then grouped into twelve substantive themes (stage 1c). Applying the same coding framework to all sources enabled triangulation between the accounts of staff, volunteers and villagers. Below, I consider one theme, gender relations, to examine what patterns emerged from the interactions between men and women after the tsunami. The key patterns that emerged were:

- men received the bulk of aid resources, but none catered to their specific needs as men.

- men felt traumatised and lost without their breadwinner and protector roles.

- men sought solace in alcohol, drugs and violence.

- women, excluded from decision-making, sacrificed much for their families.

- donors preferred to support families through women.

- children played no role in disaster deliberations.

I use quotes that illustrate substantive trends.

\section{Masculinity and Disasters in the Existing Literature}

There is a small but powerful literature on gender and disasters. Its authors have highlighted: the exclusion of women from decision-making structures centring on disaster-related activities (Enarson and Morrow, 1998;Dominelli, 2014); women being denied their fair share of aid (Pittaway et al, 2007); and increase of domestic violence against women and children in refugee camps (Pittaway and Rees, 2006; Houghton, 2009; Parkinson and Zara, 2013). The smaller literature on men's roles in disasters: utilises feminist work that reconceptualises patriarchal relations; highlights men's social dominance and privileging in both public and private arenas (Pacholok, 2009, 2013); emphasises women's dissatisfaction with their subordinate social position (Zara et al., 2016); and presents men's dominance in management, and policy-making including those involving service provision (Enarson and Morrow, 2009; Dominelli, 2014; Pease, 2014). This body of work, critical to understanding masculinity(ies) in disasters, shows that men dominate among first tier responders - the police, military, and firefighters who evacuate people during disasters and take them to places of safety. Once evacuated, victim-survivors are cared for by second tier responders composed mainly of women health professionals and social workers. This division of labour is highly gendered: men do the tough, heavy work and make policy; women care for others (Enarson and Morrow, 1998; Dominelli, 2014; Alston, 2017).

Masculinity has been analysed through three key paradigms: traditional patriarchal masculinity; socially constructed masculinity(ies); and a blurring of the boundaries between masculinity(ies) and femininity(ies) as in transgender identities. Traditional patriarchal masculinity, defined as biological and hormone or testosterone-driven is uncontrollable (Fine, 2017), places men in a binary relation that situates women as weak, submissive and embedded in nationhood (Yuval-Davis, 1997). Masculinity is treated as essentialised, unitary and immutable. Biological urges drive men's abusive behaviour including violence against women and children. Armed conflicts express archetypal biologically-driven masculinity in diverse geographical regions (Wilmer, 2005). Women are reified as sex objects and women's bodies are used to sell any commodity in the marketplace or represent the nation (Yuval-Davis, 1997). Alcohol and drug misuse become contributory factors in excusing men's 
deplorable behaviour, absolving them of personal responsibility for its perpetuation. In the IIPP research, Sri Lankan cultural traditions locked men and women into traditional patriarchal social spaces and positions (De Mel et al., 2013).

In contrast, feminist paradigms document masculinity(ies) as socially constructed around gendered power relations that privilege men over women (Butler, 1990). Crenshaw (2017) has exposed the intersectional and interactive dimensions of masculinity(ies) and gendered power relations that simultaneously shape all dimensions of women's identity. Kimmel (2010) questions the relevance of binary tropes. More recently, transgender people have challenged the masculine-feminine binary (Munro, 2007) and boundaries between men's and women's identities. Concerns about the treatment of LGBTQ+ gendered identities before, during and after disasters were not raised by our interviewees, but these issues require examination in their own right through specific research. Additionally, Showalter (1990) indicates that men who fear the modest gains achieved through feminist action can impede women's autonomous progress. The IIPP research highlights this as men taking control of family finances including the income women earn. Gendered analyses regarding who receives aid show that men receive most of it through culturally sanctioned patterns of distribution (Pettigrew et al., 2007; Dominelli, 2012c). I adopt a social constructionist view of gender relations to explore the data and understand the complex, differentiated lived experiences of men and women tsunami survivors in southern Sri Lanka. Socially constructed relations are perceived as amenable to change. Thus, masculinity can be changed by people acting to transform social relations (Gardiner, 2004).

Feminists at the forefront of challenging hegemonic patriarchal constructions of masculinity(ies) hold men accountable for their behaviours (Ferber and Nelson, 1993; Gardiner, 2004; Dominelli, 2019). Globally, traditional characterisations of men retain currency in popular discourses and country-based cultural discussions about white working-class men, e.g., those 'left behind' in Trump's America and Brexit Britain. The 'left behind' phenomenon is driven by deep-seated, longterm trends of well-paid blue-collar jobs disappearing as multinational companies move opportunities to countries where labour power is cheaper and unorganised (Goodwin and Ford, 2014; Luhby, 2016; Mishra, 2017; Cowan, 2018). Moreover, governments pass policies that leave unchallenged multinational company decision-making around disinvestment and indifference to the plight of ordinary people as the social fabric and economy around them decays (Piketty, 2012, Mishra, 2017). In the IIPP research, villagers complained that multinational companies profiteered from buying coastal lands to invest in tourism, thereby preventing those previously living there from rebuilding their lives.

Current hegemonic social constructions of Western masculinity(ies) privilege white middle-class men over all women, and subordinated masculinities, e.g., white and black working-class men, young men (Connell, 2005) and men in the global South. Under heteronormativity, white, Western middleclass men define normality. Normality is privileged and does not have to justify claims to privilege or the assumptions underpinning men's dominance, particularly in appropriating power, resources and violence. Researchers on generalised domestic violence in society, seldom analyse gendered relations in disasters where men's violence against women, children and subordinated men characterises their lives, including in camps where safety should be taken as given. Intimate violence against women and children in disaster situations often rises in a 'hockey stick curve' because it increases substantially above pre-disaster levels (O'Neil, 2016). In Sri Lanka, De Mel et al., (2013) report that the majority of Sri Lankan men and women consider violence acceptable in disciplining women.

Additionally, men dominate decision-making structures in aid organisations, enabling men to affirm their higher social status, ascribed 'superiority' and entitlement to goods and services (Pacholok, 
2009). This socially constructed configuration of heteronormativity is embedded in power relationships of dominance which cast power as an unnegotiated 'zero-sum' game (Parsons, 1957). Despite men's dominance, some patriarchal elements affect them adversely. Privileging does not protect men from patriarchy's negative consequences regarding their emotional well-being. Men having difficulty expressing their emotions and dealing with grief and losses during and after a disaster miss out on help offered to those who admit traumatic loss and grief (Kimmel, 2010; Akerkar and Fordham, 2017).

Masculinity, expressed in normal social interactions and before, during and after disasters affirms men's dominance in tropes that impact differentially upon men, women, boys and girls (Connell, 1995; Wendt and Zannettino, 2014; Enarson and Pease, 2016; Akerkar and Fordham, 2017). Women are more likely than men to die or be injured in natural disasters; and more children than adults become casualties (Neumayer and Plümper, 2007). Moreover, children become traumatised if they lose family members, so establishing familiar routines (Hafstad et al, 2012) and acknowledging children's agency is vital for their survival. Children are more liable to exploitation by predators, especially men in organised crime and paedophilia, looking for children considered 'orphaned' if unaccompanied by parents or close kin for sexual predation, smuggling or trafficking purposes (Montgomery, 2011). Such exploitation occurs in chaotic post-disaster situations because men retain socially and culturally sanctioned power over women and children. Patriarchy, as the power of men over women, produces local systems of inequitable gender relations that are context specific (Abramovitz, 2018), tying masculinity to particular cultures and locales (Dominelli, 2012b; Pacholok, 2013). In disasters, men play protector roles which prioritises men as firefighters, police and military men who assume dominant roles in emergency situations to evacuate people (Zara et al., 2016). Women, ascribed caring roles, look after children, older people, sick relatives and neighbours, accept decisions made by men who evacuate people to places of safety staffed by women (Dominelli, 2014; Akerkar and Fordham, 2017). Men in these roles are not considered unusual and role enactment is rarely remarked upon. Men become traumatised and disoriented as victim-survivors (Fordham and Ketteridge, 1998) if they lose their provider roles when disasters deprive them of the means to earn livelihoods. Women who lose their incomes are expected to develop alternatives or receive modest NGO funding to do so.

Early research highlighting increases in domestic violence following disasters concerned bushfires in rural Australia (Tyler and Fairbrother, 2013). Fire disasters regularly devour large swathes of this territory. Prior to 2019, particularly traumatic were those of Black Saturday, 7 February 2009 when 1.1 million acres of land burnt in the state of Victoria and 173 people died. Their cultural stereotypes of men as real men demanded that they:

- Stay to play the protector role, defending their homes, often requiring women and children to do likewise (women prefer to leave with their children).

- Control nature (and women).

- Reject the feminine trope of evacuation by staying (Tyler and Fairbrother, 2013).

Where men refuse to evacuate when women would have liked to, women and children remained, becoming casualties of the fire alongside their menfolk (Parkinson and Duncan, 2016). Women, whether as victims, or victim-survivors allow men to assume decision-making powers because men's supremacy is culturally sanctioned and exemplifies one social construction of women's susceptibility to disasters. Pacholok $(2009,2013)$ argues that men constantly reproduce hegemonic masculinity by finding innovative ways of affirming status, as they did during the 2003 fires in British Columbia, Canada.

Sri Lanka avows equality between men and women while failing to implement this in practice. It has endorsed the United Nations' initiatives supporting women's equality through the decade of women in the 1970s; conferences on women; conventions on women, the most important being CEDAW, 
the Convention for the Elimination of Discrimination Against Women; and Beijing Platform of Action (1995) which sought to embed women's equality in all countries. That this goal remains unrealised is tragic. The Beijing Platform of Action included a commitment to eliminating all violence against women and redefined women's rights as human rights to engage men in ensuring women's equality. The UN's Millennium Development Goals (MDGs) and Sustainable Development Goals (SDGs) have pursued gender equality across the world, particularly in the global South (UNDP, 2018). Yet, the IIPP research indicates that after the tsunami, women in southern Sri Lanka faced increased levels of violence, and unequal access to decision-making and governance structures.

Aid workers, donors, and NGOs seldom acknowledge men's specific needs as men, despite their victim-survivor status. Men aggrieved because the disaster has prevented their (re)gaining livelihoods, e.g., lacking boats for undertaking traditional fishing roles, become angry and feel powerless. However, they lack resources for coping with their new reality. Unaddressed, feelings of powerlessness fester, allowing men to express their frustrations by engaging in violent behaviour against women, children and 'weaker' men. Personal and structural powerlessness hinders men fulfiling their provider roles and facilitates their harming others in positions of lesser power. And, they become less willing to embrace change (Milnes and Haney, 2017).

\section{Results and Discussion}

Enarson and Marrow (1998) argue that gender relations, evident throughout the disaster cycle, encompass physical and psychological impact, exposure to and perceptions of risk, men's and women's preparedness, responses to warnings, emergencies, recovery, reconstruction and attitudes towards change. The IIPP data demonstrate that men who fail to resume their traditional provider and protector roles are more likely to harm women, children and other men. Meeting their needs can safeguard women and children from men's violence.

\section{Men are Destabilised by Losing Fishing Livelihoods}

Fishing in southern Sri Lanka is an economic activity traditionally dominated by men and tied to traditional expressions of masculinity that configure men's and women's places in society. Women are prohibited from fishing while men enact their provider roles to assure family income through fishing. Losing this livelihood destabilises men's sense of themselves: who they are; and their place and roles in society. All men, even young ones, have specific roles to play in fishing villages. A villager (man) says:

'[Men's] main income was from the fisheries industry. Most went on boats into the deep sea to catch fish. When they went to mid-sea, they did not return home for 10 to 15 days until they secured a good catch.... When they came back home, they would bring...a fair income...earned after deducting the expenses for food... which was given to them by the owner of the boat. When they returned home, they would clean the boats, mend the nets and dry them. They prepared the boats to go out again after a few days. The youth are responsible for preparing the boats and nets for the trip. They would buy the food, fuel the boat, load the nets and so on'.

A villager (man) summarises the appalling position confronting men as providers without their fishing apparatus. Below, he highlights men's inability to cope with change and resorting to alcohol:

'Middle-aged men had lots of drawbacks due to losing their employment and having to restart life again. The men had to find money to care for the family....[and] the children to go to school. 
It was a big job for them to find money to repair the houses, buy furniture...[provide for] cases in which family members either had died or got injured. The other thing is that they are not used to doing any job other than fishing. For them starting something new is not easy. Usually many fisher community [men] are used to alcohol and with the money [aid] they got, men's consumption of alcohol became high'.

Concerns about livelihoods remained uppermost in villagers' minds, years after the tsunami wreaked its ravages on peoples, communities and lands. Another villager (man) claims that responding to these concerns could spark resilience in men and women:

'Some people still have not got their lost jobs...boats, or fishing equipment. Many women who were making rope lost their machines. [Replacing] these would not be expensive. If they can be given such machines, they can earn money. It will be good if some... place could be provided to park the boats....to have storage places to store fish when there is plenty'.

The IIPP data shows that not all fishermen received boats, motors, or nets to replace those lost to the waves. Following the tsunami, some men became carpenters; others assumed government jobs. However, even these missed their fishing lifestyles and felt lost and unhappy. Despite five years having passed, men still found it difficult to talk about their tsunami experiences. One said:

'I am [name] and I was a fisherman. My family has my wife, daughter and son -4 of us altogether. We had bad experiences of the tsunami. We got donations and Rs 30,000 from the government. But it was not...enough for all the damages that we had. I am sad as now I have nothing to do'.

Different expectations about the extent to which men and women demonstrated resilience in rebuilding their roles and family lives after the tsunami prevailed. Men's powerlessness as providers was widely recognised, if not tackled. Despite desperate circumstances, women were ascribed greater resilience and capacity to provide family incomes. An aid worker (woman) states this pithily:

'I noticed that men's economic activities were threatened. Completely. Not only sometimes because the fields were destroyed, irrigation systems were destroyed so they were basically doing nothing. They wouldn't do anything for their survival because society gave these responsibilities to women. If men's economic activities were hampered, they were excused by society because they were limited in what they could do. The men are trying to do something, but they are helpless because it's not their fault that everything has been destroyed and they are not doing anything. Women are not excused by society. They are supposed to solve whatever problems they face....[and] take care of the household and children.'

Both men and women suffered long-term trauma engendered by huge losses. However, their feelings and responses are individualised. This fisherman explains:

II was a fisherman by profession. I had a wife and three daughters...but I lost two girls in the tsunami. We lived in the 100-meter zone. It [day of tsunami] was Poya Day [holiday], so the whole family was at home. What happened to us is very sad and...difficult to talk about....We lost two daughters. My wife and I suffered both mental and physical damage. She [wife] still feels traumatised about what happened....I don't want to talk about it....l exist in a daze'.

Without fishing to enact provider roles, men felt powerless, without purpose and rudderless. Losing their fishing boats undermined their sense of traditional masculinity by destroying their capacity to act as providers within their household. This outcome was complicated by the grief men felt about 
their losses, but they were not offered trauma-counselling, bereavement groups or other psychosocial interventions. Young men were similarly affected. A man villager claims, 'Some of the young [men] had lost their boats and fishing things and were sad'. Social expectations also frame evaluations of young men's responses to the tsunami and defined their community responsibilities.

\section{Drink, a Source of Solace and Violence}

Men sought solace in alcohol and violence. Men's responses to disaster are diverse, some are helpful; some dysfunctional. A villager (man) highlighted helpfulness by saying: 'Our boys were very good, they helped others who came to clear the dirt, bury the bodies, and clean the houses'. Another village man added, 'Some bad things also happened. Some of the boys got to drink arrack and began to fight. Some boys became lazy'. Consequently, matters did not improve. Another villager (man) continued:

'There were...problems because most of the young [men] who were in the fishing industry lost their jobs and....became very lazy. They did not want to go back to the sea for some time. Some...youth got used to spending their time doing nothing and...got used to consuming alcohol'.

By obeying traditional cultural protocols, men and women failed to engage with change. Another villager (man) deplores men's drink for underpinning domestic violence:

'It [boat] will get polluted. [Women] are not supposed to touch anything. So, women were completely excluded...The kind of domination that was built among men created many difficulties for women because alcoholism was very high. Men after coming home from fishing in the morning, they drink and sleep. That's all they do. Wife battering is very common'.

Men's misuse of alcohol provided emotional solace despite contributing to violence against others, including abusing women. The community deemed such responses inappropriate but had limited mechanisms for eliminating men's anger or assisting them in controlling their lives and moving beyond grief.

Gender relations also adversely impacted overseas women aid workers by subjecting many to violence and abuse. One Western woman aid worker described their experience in public transportation as follows:

'If you're on a bus...[men] would try and touch you and put their hands up our skirts and down our tops. They would stare at us....and made you feel really uncomfortable. We wanted to come back to [home country] just for that...so the men weren't perving on us'.

Another woman aid worker spoke of a woman colleague's inappropriate behaviour because her personal behaviour damaged the entire group's standing and confirmed gender stereotypes:

'[Name] had a relationship with a Sri Lankan boy...and had a real problem...he hit her on the face...They ruined the reputation of our project...They ruined the reputation of foreigners because Sri Lankans already have got the wrong idea about foreign girls'.

\section{Aid Ignores Men's Specific Needs}

Men received no support to deal with the traumatic effects of the tsunami on their roles in families and communities. The lack of appropriate support for men as men, made resuming normal life 
routines tough if they could not assume normal fishing provider roles. A villager (man) hints at marginalised masculinity(ies) when feeling subordinate to a boat owner:

I w'ould like someone to help me with fishing equipment so that I can earn more money. Now, I have to depend on the owner of a boat. I can go to work only if he invites me. Otherwise, I will have no job, but if I have my own equipment I can earn more and help a few more youths. Fishing is seasonal, and it would be good if other income generation programmes can also be introduced so that the young men can do these when they are not able to go to sea'.

Donors could assist men to fish and train to fulfil their provider roles. This villager (man) pleads:

'[Men] need livelihood support. Most [men] have given up fishing [because]...they have no place to store their equipment or to keep a boat. It would be helpful if some person or organisation can provide a store so that the people can leave their fishing equipment when they come to the shore until they go back again. Also, providing an alternate trade that they can get involved in during the off season when they are not able to go to sea. It should be given with training and financial support to start up. It can be in the form of a group activity'.

Fishing aid given to non-fishermen highlighted aid distribution problems. One villager (man) speaks out, 'People who have never gone fishing have got fishing boats'. Another villager (man) critiques poor aid distribution:

'The real people who were fishermen did not get fishing equipment. If would be helpful if the authorities would find the real owners before providing support so that the real owners would benefit. They need proper coordination for providing relief and distributing items. There were a lot of politics. Therefore, people did not get what they should get, and the friends of the people who came to distribute things benefitted'.

Villagers felt strongly about poor fishermen being excluded from receiving their share of assistance following the tsunami and demanded redress. Others identified systemic faults including inadequate aid distribution systems. Some suggested corruption in accessing resources because people knew the 'correct politicians'. One villager (man) claims:

'Some...people still have not got any support, especially the people who were living on traditional fishing using large nets. These nets are costly, and people are not able to buy them. Whatever support the fisheries department did, was not well coordinated. There was political support and only those people who were good with politicians received help'.

Despite men's dominance, those lacking connections for getting aid goods like boats, motors, or nets to resume livelihoods as fishermen, descended into despondency and despair. Although receiving most of the aid, men's specific needs as providers and protectors were generally ignored. Emotional support to deal with loss and emotional bewilderment was neglected by donor agencies. Emotional turmoil led to men abusing substances, especially alcohol, and increased violence against women, children and other men. Men's failure to get to grips with post-tsunami life or be supported by postdisaster aid interventions to do so, meant that they and close family paid the price.

Men victim-survivors asked NGOs and donors to provide equipment and training to build alternative sources of income including during non-fishing seasons. Donors need to engage seriously with men's emotional needs especially dealing with loss and grief and training them in alternative livelihoods to facilitate their roles as providers and protectors. Our results did not suggest internal challenges to 
existing patriarchal relations. All change was experienced and interpreted within the dominant patriarchal cultural trope endorsing men's dominance (De Mel et al., 2013).

\section{Women, Despite Exclusion from Decision-Making, Sacrifice Much for Their Families}

Women were expected to show resilience by coping with whatever crossed their paths and sacrifice their dreams to ensure family survival and well-being. Within families, women supported men around emotional inarticulateness. However, women's options in establishing income generation projects if they lost husband heads of household and providers was culturally limited. In southern Sri Lanka, women, considered polluting, are disallowed from entering a boat or replacing fisher husbands on boats post-tsunami. Fathers, husbands and brothers made decisions for them. A woman aid worker commenting on women's exclusion and gender relations following the tsunami says:

'For example, all the aid goes to the brother because she didn't have any right to it. Her brother was in the hospital, so they didn't get any help for a long time. The brother had a different idea what to do with this money. She lived here in this house, but she did not have any input into what happened with the aid they got'.

A villager (man) also comments on the limited opportunities for changing patriarchal gender relations:

'There were men's forums and women's forums.... We discussed within them why it is important to think about what should be done, because these are fishing villages and in fishing villages women are in a really lower position because men are very dominant, unlike in every other culture where women participate almost equal[ly]. In [Sri Lanka's] south, there have been traditional beliefs where women are not supposed to be on a fishing boat'.

Cultural prohibitions on women fishing could not be transcended, despite family hardship. These problems were complicated further by ineffective aid distribution systems. Many villagers maintained that not all fishing families received their aid entitlements. Each family could receive donations from various people and organizations and Rs5000 monthly and Rs30,000 for house repairs from the Sri Lankan government. Those receiving this amount deemed it insufficient. However, some tsunami widows received nothing because only 'the man, as head of household' could claim it.

Another villager (man) referred to the adverse impact of institutional violence on gendered daily life caused by civil war between the government representing the country's Singhalese Buddhist majority and its Muslim minority acting through the LTTE (Liberation Tigers of Tamil Eelam or Tamil Tigers):

'The environment here is very bad, affected as it is [by]...conflict. Women's basic survival is threatened. They have to look for other ways to support their families. I noticed women in one village...went out in the morning to beg. They would beg for something and bring back to their children, some rice or some soup'.

Men and women are differentially affected by disasters. Women outnumber men among tsunami casualties and suffer more physically and financially. A woman aid worker highlights gender inequality: 
'I have the figures, the majority of those affected were women....Women's husbands died. The men, the breadwinner in the family died and the women didn't have any way of surviving. There were so many gender issues there. But people had not looked at these things and I think most of the support work came on either constructing a house for them or giving them certain things. Now in the villages that I worked in, there were people who were not affected, and they were able to get a lot of funding, a lot of support. Those who were very quiet and couldn't do anything, didn't get anything at all.... think the organization was not very good. The people who were living on their own got many things and the people who were living in camps didn't get anything. I met a woman who had a house... an ancestral house. She was living very close to the shore and...living alone without a man...a very quiet woman. Now she is living in a very small hut. The water comes in when it's raining, and nobody has approached her. When I asked the other women why she didn't get anything, the other women said, 'She has to go, she has to go and talk. That's how she can get things'. But this woman is not the type...who would go and ask for anything. But...a[nother] woman....got nineteen steel cupboards'.

This quote suggests that women's own personal traits further complicate gender relations. Society hoisted onerous responsibilities on women by expecting them to secure family incomes when men lost their livelihoods. Women were required to sacrifice themselves for their family and disregard their own aspirations. One woman whose husband lost his boat and sank into despondency and drinking claims that she had not wanted to get married. She wanted to study to become a teacher. According to a neighbour, she married as tradition stipulated. After the disaster struck, she had no choice but:

'...to take a job in a garment factory which she has [had] to because her husband drinks too much...and she's got a small child...and she's never [at home] because she is always working'.

This story, among others, exposes the silencing of women's own stories and wishes. Income generation projects empowered women through opportunities to provide for families.

Aid interventions could have positive outcomes for women. Women, supported by a variety of programmes including microcredit schemes, worked together and rebuilt their lives after the tsunami more successfully than men. However, their endeavours became invisible when described as being done by 'people'. A woman aid worker articulates this:

'After the tsunami, women were more empowered. Women got more involved in savings programmes, income generation programmes. They would join in whatever programmes were organized. They would go and meet government officials. Before this, these women would only do housework, look after the children.....Now, they come for meetings organized by various organizations and have learned a lot. They would form small groups of five and get donations to become involved in small income generation programmes. Forming a group was a requirement for the savings programmes. In it, when one person takes out a loan, the other four in the group would take responsibility to see that the repayment is made. Sometimes they take the loan as a group and work together on an income generation programme...Some groups purchased fish and sold these in the open market. Some people would prepare cooked food and sell it. Others would run a small grocery shop. These people were supported by organisations such as [local NGO]'.

Although men appropriated women's earned income, women benefitted from long-term support and development. This enabled women to become self-empowered and assume control of decisions that strengthened their capacity to care for families and communities. One woman confirms that: 
'In the past we just stayed at home, did the cooking and looked after the children. But [woman aid worker] came and met with us. Now we have our own women's committee. [Aid worker] met with another organisation and organized training programmes on how we should manage the money we got. This made us get into the habit of saving [not done before]. We now meet once a week and...plan programmes for our group. We have our own savings programmes. We were introduced to government officials. We are now strong enough to voice our own opinions'.

Women's empowerment strengthened women's engagement in the local labour market and with officialdom.

Cultural expectations about modesty affected women's responses and willingness to accept help (Rezwana, 2016). Some outcomes were extremely upsetting. Another woman aid worker explains:

'Women and children were killed for social cultural reasons. I came across situations where women were almost saved and there was.... mother who was telling me that this girl was drowning and somebody gave her a hand to reach her. She was almost lifted out. When she realized that she didn't have any clothes on her body...she let the hand go...she let herself drown...Her feeling of shame was much stronger than the fear of death'.

Women grieved their losses deeply, upheld cultural norms in their suffering and received overseas assistance to address their situation, as this woman aid worker articulates:

'[There was a] very positive programme where they [women aid workers] reached out to women and had taken them out of the grief they were suffering....Women were refusing to enjoy their life. Women were refusing to go anywhere. Women were refusing to laugh....They were feeling like, 'How can we laugh?...Our people died. Our children died. This happened to us. We are not supposed to laugh'.

Like De Mel et al., (2013) IIPP results indicate that traditional patriarchal gender relations and cultural expectations dominate in southern Sri Lanka. Traditional gender relations configured social relationships following the tsunami and changes occurred within patriarchal, cultural tramlines despite women being 'empowered' through income generation projects by becoming agents in ensuring family income security and daily life. Women could not challenge existing expectations of their social roles as evidenced by widows being disallowed from undertaking fishing activities or entering a boat because they would pollute it and bring bad luck. Consequently, women engaged in income generation activities linked to their traditional roles: buying and selling vegetables, preparing food, sewing, caring for children and elders. Women, excluded from aid distributed goods and services, would not self-advocate because it was frowned upon, and they lacked connections to powerful others who would facilitate access to aid if a man head of household were absent for whatever reason.

\section{Children as Victim-Survivors}

Gender relations also implicate children. Their differentiated experiences mean children are more likely than adults to suffer emotionally, physically, financially and become casualties (Cas et al., 2014). Their exclusion from decision-making was articulated years later in teenager focus groups. The loss of family members and schools affected children's entire well-being, safety, and becoming prey to predators, especially paedophile rings (Montgomery, 2011). Children who survived the 
tsunami had enormous psychosocial needs including clinging to mother, adjusting to loss, grief and fear of water. One villager (man) recalls:

'Children suffered a lot, they not only lost belongings but some...lost one or both parents...Children were caught by the waters and injured...Some...could not sleep at night...They were scared to leave their mothers'.

The children receiving aid including computers had positive experiences. A villager (man) comments:

'...children benefitted in many ways. They were happy as they were able to experience the friendship of [overseas] students. They had the opportunity to play; learn new activities. They were able to talk freely with the students and discuss some of their problems'.

During the tsunami, adults shielding children from its horrors, rarely consulted them over its wider ramifications. Talking about their experiences years later as teenagers remained difficult. Their views as a focus group are summarised below:

'The children's education was severely disrupted as some schools were destroyed by the tsunami. Children lost their school equipment, notes accumulated over a long time, school uniforms, school certificates and other things. Some schools that were left standing were used as lodgings by people who had been evacuated to them, while others were closed, some permanently. Schools that were partially damaged were closed temporarily. These young people also commented on the 'bad quarrels' that ensued in the family when their fathers had lost their livelihoods and had nothing to replace their lost income. They remarked on how in these situations their fathers would drink, take drugs, and become violent towards their mothers and even them'.

These young people highlighted domestic violence, their inability to halt their fathers' violence and relief workers' failure to utilise their knowledge, energy and potential in rebuilding their communities. They complained that excluding children by emphasising their dependency represented a lost opportunity in reconstructing communities. This raises the issue of undertaking future research to hear children/young people's voices in depth and at length.

\section{Conclusions}

The IIPP research emphasises the interdependent social interactions stipulated by traditional patriarchal cultural relations between men, women and children that facilitate the reproduction of the traditional gender binary that prevails in the 12 village research sites. It also highlights men's inability to address their emotional vulnerabilities and/or rebuild their livelihoods to conduct their breadwinner roles in post-tsunami southern Sri Lanka. They lose their status in society, become depressed and/or abusive through violence and other unacceptable behaviours. Addressing men's specific needs as men is crucial for their emotional well-being and safeguarding the interests of women, children and subordinated men, albeit within traditionally defined patriarchal cultural norms. Despite the small geographical area, the IIPP results raise fundamental challenges for aid workers to tackle. Rethinking masculinity and understanding the imperatives men face as providers and protectors in upholding traditional masculinity before, during and after disasters is critical to disaster responses that create safe, resilient communities better prepared to cope with future disasters, attend to differentiated experiences of a disaster, and address specific needs among men, women and children. The research participants have given policymakers and practitioners a clear agenda for meeting men's needs as men fulfilling their provider and protector roles and empowering women to ensure family safety and well-being. 


\section{Acknowledgements}

I wish to thank the British Economic and Social Research Council (ESRC) funded the Internationalising Institutional and Professional Practices (IIPP) Project (Grant number ES/F031505/1) for making this research possible.

There are many people who made this research project possible - practitioners, politicians, academics, researchers, and students, UK-based and Sri Lanka-based, and I would like to thank you all for contributing your time, energy and goodwill to it, on grand occasions and small ones. Others have contributed to developments in the villages, and some have come from countries in Asia and North America. Your work is referred to in other papers. Some researchers have asked not to be named, and to have their anonymity respected, and so I have not mentioned anyone by name. In any case, you know who you are. I thank you from the bottom of my heart.

\section{References}

Abramovitz, A. (2018) Regulating the Lives of Women: Social Welfare Policy From Colonial Times to the Present. London: Routledge.

Akerkar, S., and Fordham, M. (2017) Gender, Place and Mental Health Recovery in Disasters: Addressing Issues of Equality and Difference. International Journal of Disaster Risk Reduction, 23 (March): 218-230.

Alston, M. (2017) Gendered Outcomes in Post-Disaster Sites: Public Policy and Resource Distribution. In Griffin Cohen, M. (Ed) Climate Change and Gender in Rich Countries: Work, Public Policy and Action. London: Routledge, Earthscan. Chapter 9, pp. 133-149.

Berger, P. L. and Luckmann, T. (1967) The Social Construction of Reality: A Treatise in the Sociology of Knowledge, London, Penguin.

Butler, J. (1990) Gender Trouble: Feminism and the Subversion of Identity. London: Routledge.

Cas, A., Frankenberg, E., Suriastini, W., and Thomas, D. (2014) The Impact of Parental Death on Child Well-Being: Evidence From the Indian Ocean Tsunami, Demography, 51: 437-457. DOI 10.1007/s13524-014-0279-8.

Connell, R W (1995) Masculinities. Cambridge: Polity Press.

Connell, W. (2005) Masculinities. Cambridge. Polity Press.

Connell, R.W. and Messerschmidt, J.W. (2005) Hegemonic Masculinity: Rethinking the Concept. Gender \& Society, 19(6): 829-859.

Cowan, T. (2018) The Side Effects of the Decline of Men', Bloomberg Opinion, 14 February. On www.bloomberg.com 20 May 2017.

Crenshaw, K. (2017) On Intersectionality: Essential Writings. New York: New Press.

Daly, A. J. (2007) Outbound student exchange at Australian and New Zealand universities: The effects of pre-departure decision-making, in-country experiences and post-sojourn outcomes', doctoral thesis submitted to Griffith University, Nathan, Queensland, Griffith University.

De Mel, N., Peiris, P., and Gomez, S. (2013) Broadening Gender: Why Masculinities Matter: Attitudes, Practices and Gender-Based Violence in Four Districts in Sri Lanka: Colombo: CARE.

Denzin, N. (2006) Sociological Methods: A Sourcebook. London: Aldine Transaction.

Dominelli, L. (2012a) 'Gendering Climate Change: Implications for Debates, Policies and Practices' in Alston, M. and Whittenbury, K. (eds.) Research, Action and Policy: Addressing the Gendered Impacts of Climate Change. London: Springer, 2013, Chapter 6, pp. 77-94.

Dominelli, L. (2012b) Green Social Work: From Environmental Crises to Environmental Justice. Cambridge: Polity Press.

Dominelli, L. (2013) 'Mind the Gap: Built Infrastructures, Sustainable Caring Relations and Resilient Communities in Extreme Weather Events', Australian Social Work, 66(2): 204-217. DOI: http://dx.doil.org/10.1080/0312407X.2012.708764 
Dominelli, L. (2014) 'The Opportunities and Challenges of Social Work Interventions in Disaster Situations', International Social Work, (special issue: Global Agenda for Social Work and Social Development, guest edited by Tasse A.), 57(4): 337-344. doi: $10.1177 / 0020872815598353$

Dominelli, L. (2017) 'Climate Change: Rethinking the Local for Policy and Practice'. In Sternberg, T (ed) Climate Hazard Crises in Asian Societies and Environments, London: Routledge, pp. 193213.

Dominelli, L. (2019) 'Green Social Work and The Uptake by the Nepal School of Social Work: Rebuilding Resilience in Disaster Stricken Communities'. In Bracken, L, Ruszczyk, $\mathrm{H}$ and Robinson, T (eds) (2018) Evolving Narratives of Hazard and Risk. London: Palgrave, pp. 141158.

Enarson, E., and Marrow, E. (2009) 'The Gendered Terrain of Disaster', in Enarson, E., and Chakrabarti, P.G. (eds) Women, Gender and Disasters: Global Issues and Initiatives. London: Sage.

Enarson, E. and Pease, B. (2016) Men, Masculinities and Disasters. London: Routledge.

Ferber, M. and Nelson, J. (1993) Beyond Economic Man: Feminist Theory and Economics. Chicago: University of Chicago Press.

Fine, C. (2017) Testosterone Rex: Unmaking the Myths of our Gendered Minds. Icon Books Ltd. Fordham, M. and Ketteridge, A. (1998) 'Men must Work and Women must Weep': Examining Gender Stereotypes in Disaster'. In Enarson, E. and Morrow, B. (eds.), The Gendered Terrain of Disasters: Through Women's Eyes. London: Praeger, pp. 81-94.

Gardiner, J.K. (2004) Men, Masculinities and Feminist Theory. London: Allen and Unwin.

Goodwin, M. and Ford, R. (2014) 'White Face, Blue Collar, Grey Hair: The 'Left Behind' Voters only UKIP Understands', the Guardian, 5 March. On www.theguardian.com accessed 1 January 2015.

Hafstad, G., Haavind, H., and Jensen, T. (2012) 'Parenting After a Natural Disaster: A Qualitative Study of Norwegian Families Surviving the 2004 Tsunami in Southeast Asia', Journal of Child and Family Studies, 21(2): 293-302.

Houghton, R. (2009) 'Everything Became a Struggle, Absolute Struggle': Post-Flood Increases in Domestic Violence in New Zealand', in Enarson, E., and Chakrabarti, P.G. (eds) Women, Gender and Disasters. London: Sage.

Kaufman, M. (2001) The Construction of Masculinity and the Triad of Men's Violence. In Kimmel, M. and Messner, M. (eds) Men's Lives. $5^{\text {th }}$ edn, pp. 4-18. Needham Heights, MA: Allyn and Bacon.

Kimmel, M. (2010) Misframing Men: The Politics of Contemporary Masculinities. Rutgers University Press.

Klein, H. K. and Myers, M. D. (1999) 'A set of principles for conducting and evaluating interpretive field studies in information systems', MIS Quarterly, 23(1): pp. 67-93.

Luhby, T. (2016) The Men America has Left Behind, CNN Business, 4 May. On www.cnn.com accessed 20 June 2017.

MacDonald, R. (2005) 'How Women Were Affected by the Tsunami: A Perspective from Oxfam', PLoS Medicine, 28 June, 2(6): e178. Doi: 10.1371/journal.pmed.0020178. On www.ncbi.nim.nih.gov accessed 18 June 2017.

Mathbor, G. M. (2008) Effective Community Participation in Coastal Development. Chicago, Lyceum.

Milnes, T., and Haney, T.J. (2017) 'There's always Winners and Losers: Traditional Masculinity, Resource Dependence and Post-Disaster Environmental Complacency', Environmental Sociology, 3(3): 260-273, DOI: 10.1080/23251042.2017.1295837

Mishra, P. (2017) Age of Anger: A History of the Present. Harmondsworth: Penguin.

Monaghan, L. (2002) 'Embodying Gender, Work and Organizational Solidarity, Cool Loyalties and Contested Hierarchy in a Masculinist Occupation', Gender, Work and Organization, 9(5): 504-536. 
Montanari, B., and Bergh, S (2019) 'A Gendered Analysis of the Income Generating Activities Under the Green Morocco Plan: Who Profits?' Human Ecology, 47: 409-417, https://doi.org/10.1007/s10745-019-00086-8.

Montgomery, H. (2011) 'Rumours of Child Trafficking after Natural Disasters', Journal of Children and Media, 5(4): 395-410.

Munro, S. (2007) 'Transmuting Gender Binaries', Sociological Research Online, 12(1): 1-7. doi: $10.5153 /$ sro. 1514

Neumayer, E. and Plümper, T. (2007) 'The Gendered Nature of Natural Disasters: The Impact of Catastrophic Events on the Gender Gap in Life Expectancy, 1981-2002', Annals of the Association of American Geographers, 97(3): 551-566.

O'Neil, L. (2016) 'The Link Between Natural Disasters and Domestic Abuse Flooding in Louisiana has Left Victims of Abuse Even More Vulnerable', The Atlantic, 28 September. On https://www.theatlantic.com/health/archive/2016/09/disaster-domestic-abuse/501299/

Pacholok, S. (2009) Gendered Strategies of /Self: Navigating Hierarch and Contesting Masculinities. Gender, Work \& Organization, 16(4): 471-500.

Pacholok, S. (2013) Into the Fire: Disaster and the Remaking of Gender. Toronto: University of Toronto Press.

Parkinson, D., and Zara, C. (2013) 'The Hidden Disaster: Domestic Violence in the Aftermath of Natural Disaster', The Australian Journal of Emergency Management, 28(2): 28-35.

Parkinson, D., and Duncan, A. (2016) 'Men and Disaster: Men's Experiences of the Black Saturday Bushfires and the Aftermath', The Australian Journal of Emergency Management, 31(3): 4048.

Parsons, T (1957) 'On the Concept of Political Power', Proceedings of the American Philosophical Society, 107(3), pp 232-262.

Parvin, G., Ahsan, S.M.R., and Chowdhury, M. (2005) 'Women Empowerment Performance of Income Generating Activities Supported by Rural Women Employment Creation Project (RWECP): A Case Study in Dumuria Thana, Bangladesh', The Journal of Geo-Environment, 4: 47-62.

Pease, B. (2014) 'Hegemonic Masculinity and the Gendering of Men in Disaster Management: Implications for Social Work Education', Advances in Social Work and Welfare Education, 16(2): 60-72.

Picketty, T. (2012) Capital in the Twenty-First Century. London: The Belnap Press of the Harvard University Press.

Pittaway, E. and Rees, S. (2006) 'Multiple Jeopardy: Domestic Violence and the Notion of Cumulative Risk for Women in Refugee Camps', Women Against Violence: An Australian Feminist Journal, 18: 18-25.

Pittaway, E., Bartolemei, L., and Rees, S. (2007) 'Gendered Dimensions of the 2004 Tsunami and a Potential Social Work in Post-Disaster', International Social Work, Special Edition edited by L. Dominelli, 50(3): 307-319.

Poisson, B., Garcin, M., Pedreros, R. (2009) 'The 2004 December 26 Indian Ocean Tsunami Impact on Sri Lanka: Cascade Modelling from Ocean to City Scales', Geophysical Journal International, 177(3): 1080-1090. doi: 10.1111/j.1365-246X.2009.04106.x.

Rezwana, N. (2016) Disasters and Access to Healthcare in the Coastal Region of Bangladesh: A Gendered Analysis. Durham: Durham University, Ph D Thesis.

Rushton, A., Gray, L., Canty, J., and Blanchard, K. (2019) 'Beyond Binary: (Re)Defining 'Gender for $21^{\text {st }}$ Century Disaster Risk Reduction, Research, Policy and Practice', International Journal of Environmental Research and Public Health, 16: 3984, doi:10.3390/ojerph16203984.

Showalter, E. (1990) Sexual Anarchy: Gender and Culture at the Fin de Siècle. London: Viking Press. Teichler, U. (2009) 'Internationalisation of Higher Education: European Experiences', Asia Pacific Education Review, 10(1), 93-106. 
Tomita, T., Imamura, F., Irikawa, T., Yasuda, T. and Kawata, Y. (2006) 'Damage Caused by the 2004 Indian Ocean Tsunami on the Southwestern Coast of Sri Lanka', Coastal Engineering Journal, 48(2): 99-116. DOI: 10.1142/S0578563406001362

Tyler, M. and Fairbrother, P. (2013) 'Gender, Masculinity and Bushfire', Australian Journal of Emergency Management, 28(2): 1-6.

UNDP (United Nations Development Programme) (2018) Gender Equality as an Accelerator for Achieving the Sustainable Development Goals. New York: UNDP/UNWomen.

Wendt, S. and Zannettino, L. (2014) Domestic Violence in Diverse Contexts. London: Routledge. World Bank. (2005) Gender-Responsive Social Analysis. Washington, DC: World Bank.

Yuval-Davis, N. (1997) Gender and Nation. London: Sage.

Zara, C., Parkinson, D., Duncan, A., and Joyce, K. (2016) 'Men and Disaster: Men's Experiences of the Black Saturday Bushfires and the Aftermath', The Australian Journal of Emergency Management, 31(3): 40-48.

Wilmer, Franke, 2005. The Social Construction of Man, the State and War: Identity, Conflict and Violence in the Former Yugoslavia. London: Routledge. 